\title{
ECONOMIC CONSIDERATIONS AS A FACET OF SUBSTANTIVE UNFAIRNESS OF CONSUMER CONTRACT TERMS IN THE PRACTICE OF POLISH COURTS
}

\author{
Piotr Sitnik
}

ABSTRACT

It is trite law and a common cliché reiterated in the judgments of the Court of Justice of the European Union that the economic situation of a consumer subjected to a purportedly unfair consumer contract clause is generally impertinent. This general tenet of the European regulation of unfair terms in consumer contracts is borne out particularly by Article 4(2) of Council Directive 93/13/EEC of 5 April 1993 on unfair terms in consumer contracts, under which assessment of the unfair nature of a term shall not encompass an inquiry into the adequacy of the price and remuneration, on the one hand, as against the services or goods supplies in exchange, on the other, in so far as these terms are in plain intelligible language. Despite this seemingly bold orientation towards the formal side of the unfairness assessment, efforts have been made to inject into the judicial exercise of discretion a degree of consideration of the economic standing and interests of both the consumer and the trader involved in the particular dispute at hand. This has been done primarily by reference to the "significant imbalance" requirement pursuant to Article 3(1) of the Directive. The paper reviews an extensive crosssection of judgments handed down in Polish courts based upon the Polish transposition of the Unfair Terms Directive to show that the courts have on numerous occasions ventured outside the boundaries delineated by traditional legal analysis (even beyond the flexible bounds of purposive interpretation) to scrutinize the size and gravity of the economic burden the term under scrutiny is liable to impose upon the consumer relative to its economic strength on the market.

Key words: substantive unfairness, Directive 93/13, unfair terms, consumer contracts, Polish case law, Polish courts

LL.M., City Law School, City, University of London, e-mail: piotr.sitnik@city.ac.uk. 


\section{INTRODUCTION}

Article 4(2) of Council Directive 93/13/EEC of 5 April 1993 on unfair terms in consumer contracts" (hereinafter as "the Directive" or "Directive 93/13") precludes an inquiry into the price or remuneration of a good a service regulated by a disputed consumer contract term relative to their quality. That a court faced with a potentially unfair term could not delve into the economic consequences thereof, including its impact on the economic situation of the consumer, has become a cliché frequently reiterated by courts and commentators alike 2 . The substantive test of unfairness, enshrined in Article 3(1), is couched in exclusively legal terms, and mandates that courts have regard to a term's detrimental effect on the balance of rights and obligations between the trader and the consumer, thus tilting that balance towards the former and against the latter. It was not before early 2014 that the Court of Justice of the European Union had to grapple with the problem whether the formulation "significant imbalance" allows that the costs charged to the consumer by such a term have, as regards that consumer, a significant economic impact having regard to the value of the transaction in question, or that only the effects of such a term on the rights and obligations of the consumer must be taken into consideration ${ }^{3}$. There, the Court diplomatically held that the question whether that significant imbalance exists cannot be limited to a quantitative economic evaluation based on a comparison between the total value of the transaction which is the subject of the contract and the costs charged to the consumer under that clause $e^{4}$.

OJ L 95, 21.4.1993, pp. 29-34.

2 See e.g. Michael Schillig, "Directive 93/13 and the Price Term Exemption: A Comparative Analysis in the Light of the Market for Lemons Rationale", International and Comparative Law Quarterly 60(4) (2011): 933-936; Irina Domurath, Consumer Vulnerability and Welfare in Mortgage Contracts, Oxford: Hart Publishing, 2017, 93; Paolisa Nebbia, Unfair Contract Terms in European Law: A Study in Comparative and EC Law, Oxford-Portland: Hart Publishing, 2007, 124-131; among some recent CJEU case law, see: Case C-448/17 EOS KSI Slovensko s. r. o. ECLI:EU:C:2018:745, paragraph 60; Case C-51/17 OTP Bank Nyrt. and OTP Faktoring Követeléskezelö Zrt ECLI:EU:C:2018:750, paragraph 6; Case C-154/15 Francisco Gutiérrez Naranjo ECLI:EU:C:2016:980, paragraph 8.

3 Case C-226/12 Constructora Principado SA ECLI:EU:C:2014:10.

4 Ibid, paragraph 22. 
Notwithstanding, a parallel stream of case law has made some, albeit disorderly, exceptions to the overarching rule. The milestone as regard considering economic implications of an unfair consumer contract term under the umbrella of substantive unfairness came in the judgment of $A z i z^{5}$ where the CJEU rendered its subjective-objective standard of good faith. Since then, as we shall see below, the courts have reserved a degree of sensitivity to the burden imposed upon the consumer by the disputed term, even if this attention was zeroed in on procedural aspects, such as where a consumer is impeded from seeking a day at court because of an onerous jurisdiction clause leaving all disputes potentially arising under a contract to the exclusive jurisdiction of the courts territorially competent for the seat of the trader. The CJEU has not stopped at that, and some obiter dicta comments may be localized where, inter alia, the Court has attempted to bolster the consumer right to terminate a contract where the stronger party seeks to unilaterally impose amendments to a utility contract or, notably, it has stretched information duties levied on traders to facilitate consumer decision making that is economically informed and reasonable. In this paper I shall, first, briefly lay out the inspirational, yet scant, evidence in the case of the CJEU that the "significant imbalance" requirement of the substantive unfairness test under Article 3(1) of the Directive can be and has been used to imply consumer-specific contractual minutiae which tilted the result in the consumer's favour. Then, I shall present a selection of cases decided in Polish courts where one can see clearly that the groundwork laid in the Directive has generated a judicial attitude where regard is had to the exact dimension and gravity of the economic burden a particular disputed term happens to carry.

\section{OUTLINE OF EU LAW'S APPROACH - CRACKS IN THE MIRROR?}

The first explicit indication of deference to the economic interests of the consumer appears to have been expressed in the CJEU's judgment in Pénzügyi Lizing in November 2010, where the Court asserted that " $[\mathrm{i}] \mathrm{n}$ the

5 Case C-415/11 Aziz ECLI:EU:C:2013:164.

6 Case C-137/08 Pénzügyi Lizing Zrt. ECLI:EU:C:2010:659. 
case of disputes concerning limited amounts of money, the costs relating to the consumer's entering an appearance could be a deterrent and cause him to forgo any legal remedy or defence. Such a term thus falls within the category of terms which have the object or effect of excluding or hindering the consumer's right to take legal action, a category referred to in subparagraph (q) of paragraph 1 of the Annex to the Directive" 7 . Here, a clause conferring exclusive jurisdiction on a specific court not only deprived the consumer of the ability to appear in court, but also it was liable to trigger non-negligible financial consequences related to bearing costs of travel, transport, planning, communications etc. Indirect costs could also entail higher legal fees.

Following Aziz, in Asbeek Brusse $e^{8}$ the Court conceded that a penalty clause in a residential tenancy contract between an impecunious consumer and a real estate professional was difficult to analyse owing a clash between "an economic perspective" in line with which the contract related to an essential consumer need and involved a significant financial commitment, and "a legal perspective" that dictated the subjection of such a contract to "complex national rules about which individuals are often poorly informed" " The Court ultimately refused to examine the disputed clause as it reflected a statutory requirement, however a mention of "an economic perspective", where the actual burden suffered by the consumer was accounted for, was novel.

Competitiveness of the internal market and cost of termination were prominent considerations in the CJEU's judgment in RWE Vertrieb ${ }^{10}$. There, the Court made a somewhat courageous implication that the consumer shall be given an opportunity, where the right of termination arises due to an amendment to the underlying contract and he is notified of such an amendment coming into force, to change his utility supplier. Specifically, the Court followed up with asserting that the scope of the obligation to be imposed on the stronger contracting party (which could entail the duty to inform the consumer of available market options, even if they are offered by competitors of the trader in issue) is predicated upon such factors as the

\footnotetext{
Ibid, paragraph 54 .

8 Case C-488/11 Asbeek Brusse ECLI:EU:C:2013:341.

9 Ibid, paragraph 32.

10 Case C-92/11 RWE Vertrieb AG ECLI:EU:C:2013:180.
} 
time between the notification of an upcoming amendment and its entering into force, the information provided at the time of that communication, and the cost to be borne and the time taken to change supplier ${ }^{11}$. This could signal the Court's readiness to delve into the actual content of the notification, something that conjures up notions of substantive inquiry.

The CJEU has considered the economic interest of the consumer within the context of procedural restrictions imposed in respect of the consumer's legal remedies. For example, in $A z i z$ the Court examined a Spanish rule that did not allow the court seized of declaratory proceedings linked to mortgage enforcement proceedings to adopt interim measures guaranteeing the effectiveness of its final decision by considering the fairness of a consumer contract term upon which gave rise to the mortgage proceedings in the first place. In this connection, it was stated that such rules impair the effectiveness of protection conferred upon consumers by virtue of the Directive especially where "the mortgaged property is the family home of the consumer whose rights have been infringed, since that means of consumer protection is limited to payment of damages and interest and does not make it possible to prevent the definitive and irreversible loss of that dwelling"12.

Kásler $^{13}$ imposed on traders and suppliers wide-ranging information duties, particularly to inform the consumer of the overall economic consequences of the contract at hand ${ }^{14}$. Whilst this obligation applies at the pre-formation stage, it has found an extension as regards amendments to consumer contracts. Whilst the CJEU has not applied by analogy all the requirements enunciated in $R W E$ Vertrieb to the pre-formation stage, especially the duty to provide the consumer with an opportunity to find an alternative services supplier, such a development may be awaiting.

Andriciuc $^{15}$ may have introduced an extension in this regard as the Court included within the scope of the information duty "all the information likely to have a bearing on the extent of his commitment have been communicated to the consumer, enabling him to estimate in particular

\footnotetext{
11 Ibid, paragraph 54.

12 Case C-415/11 Aziz ECLI:EU:C:2013:164, paragraph 61.

13 Case C-26/13 Kásler and Káslerné Rábai ECLI:EU:C:2014:282.

14 Ibid, paragraph 75.

15 Case C-186/16 Andriciuc ECLI:EU:C:2017:703.
} 
the total cost of his loan"16. The last fragment is crucial - information duties, universally embraced in the CJEU's consumer law jurisprudence, may conceivably be used as a tool to bolster the position of the consumer in the event of lack of economic sophistication.

What follows is a cross-section of cases from the Polish jurisdiction concerning the striking out of purportedly unfair clauses in consumer contracts. The case law shows clearly that courts at lower instances in most cases strive to fill the void, it would appear, left by the CJEU, by resorting to economic and social considerations and searching for a justice-driven resolution.

\section{CLAUSES THAT EXCLUDE OR SUBSTANTIALLY LIMIT LIABILITY TOWARDS THE CONSUMER IN THE EVENT OF NON-PERFORMANCE OR UNDUE PERFORMANCE OF AN OBLIGATION}

Such clauses may have a far-reaching bearing on a consumer's economic interests. Examples from the Polish practice include a clause that reserved the right of a consumer to claim by virtue of a product warranty only where a claim is accepted by a courier and a protocol documenting the damage is drawn up, thus only giving the consumer an opportunity to inspect the product bought at the point of delivery ${ }^{17}$. Availability of a warranty has been excluded in respect of circumstances and events for which the trader could not be held liable and could not foresee despite taking reasonable care ${ }^{18}$. Another case involves a shop which disclaimed liability for delays in delivery of their products as long as they arose due to reasons attributable thereto, including delays resulting from the carrier's fault ${ }^{19}$. A blanket exclusion of liability in respect of "circumstances giving rise to problems or discomfort" in the context of an excursion organized by a tourist office has also been

16 Ibid, paragraph 47.

17 Judgment of the Court of Competition and Consumer Protection of 4 November 2009, ref. number XVII Amc 1066/09.

18 Judgment of the Court of Competition and Consumer Protection of 15 December 2009, ref. number XVII Amc 268/09.

19 Judgment of the Court of Competition and Consumer Protection of 26 August 2010, ref. number XVII Amc 970/10. 
stricken down as unfair ${ }^{20}$. Protection of consumer economic interest here is disguised behind a principle prohibiting traders from avoiding liability for not performing their obligations under a contract. It is assumed that attainment of certain economic objectives underpins the conclusion of every contract. These objectives may be directly pecuniary (take a mortgage loan contract) or ones that are capable of being expressed in economic terms, as is the case of contracts by virtue of which consumers strive to fulfil a noneconomic need that is however quantifiable in economic units (hotel stays, airfare, construction of an apartment or block of flats, life insurance, etc.).

Legislation comes to the aid of consumers particularly eagerly where they choose to conclude preliminary agreements in respect of the construction of real estate. The unfair clauses regime recognizes the economic vulnerability of consumers buying a home, particularly on account of the fact that normally such a purchase is conducted thanks to money raised by means of a mortgage loan. In this connection, the courts have been vigilant and have reminded traders that the contractual deadlines for the completion of apartments must be treated seriously, and no developers should be allowed to shirk liability in the event of a delay. In principle, the trader may not delay the commencement of its liability by virtue of contractual penalties for non-performance or delayed performance, by mandating that it begins, for instance, six months after a previously agreed deadline. Particularly, such changes may not be exacted by means of a onesided annex justified by urgent need, inability to complete the works in time, even if this arises by virtue of the operation of force majeure. The economic significance of having a housing unit completed on time, in accordance with the agreement concluded, normally at the formative stage of construction, cannot be overstated. The courts at times avoid resorting directly to economic terms (such as loss of the consumer, unjust enrichment of the trader), instead stressing the need for the mutual obligations in a consumer contract to be "real", that is enforceable and meaningful ${ }^{21}$.

20 Judgment of the Court of Competition and Consumer Protection of 8 July 2009, ref. number XVII Amc 264/08.

21 Judgment of the Court of Competition and Consumer Protection of 17 August 2006, ref. number XVII Amc 100/05; judgment of the Court of Competition and Consumer Protection of 28 February 2008, ref. number XVII Amc 89/07; judgment of the Appellate Court for Warsaw of 17 July 2013, ref. number I ACa 125/13. 
Further in relation to mortgage loans, the consumer must be made aware of the total real cost of the loan at the time of conclusion of the contract, and no misinformation in this regard is tolerable ${ }^{22}$.

Limitations or exclusions of liability have also been stricken down where a trader purported to burden its customer, in a contract for delivery of construction materials, with a duty to reload the materials onto a suitable vehicle in the event that delivery proved impossible on account of the lack of a paved road, mechanical insufficiencies of a bridge or another unpredicted situation; the consumer was also obliged to provide convenient access to the site $^{23}$. It was held that the clause effectively obliged the customer to pay the price for the materials in full despite the necessity of incurring additional expenses related to the non-performance of its duties by the seller. It also excluded the seller's liability in respect of the consequences of its inability to perform in accordance with the agreement arising due to circumstances beyond its control, and, crucially, predicated the performance of the agreement on circumstances on which the consumer had no bearing whatsoever. Also, such phrasing as "another unpredicted situation" was found to be too vague, thus encouraging the seller to overly rely on the exclusion clause. Economic interests of the consumer were therefore put in danger in two distinct ways: (1) by potentially imposing on the consumer a duty to provide for an alternative means of transport to ensure performance of the contract; (2) by depriving the consumer of compensation due thereto by virtue of non-performance of the contract. The consumer was obliged to relieve the trader of its duties even where the inability to deliver the materials arose due to the operation of force majeure, and in any event due to reasons unattributable to the consumer.

Further, in the context of bank accounts, the courts have policed and rendered ineffective clauses which absolved the trader of liability for adverse consequences resulting from gaining by a third party access to the balance of a consumer's internet account ${ }^{24}$, entitled the bank, for vaguely

22 Judgment of the Appellate Court for Warsaw of 20 November 2013, ref. number VI ACa 1521/12.

23 Judgment of the Appellate Court for Warsaw of 11 October 2013, ref. number VI ACa 221/13.

24 Judgment of the Court of Competition and Consumer Protection of 6 September 2010, ref. number XVII Amc 1664/09. 
defined "security reasons or other reasons unattributable to the bank", to temporarily limit access to a consumer's bank account for a period justified by the gravity of such reasons ${ }^{25}$, or ones that excluded the bank's liability for the consequences of defective performance or illegal use of telecommunication cables remaining outside of the bank's disposa ${ }^{26}$. The courts are especially alert in relation to ambiguous formulations of liability where only one reasonable construction (of many available) could potentially lead to an unfair compounding of the consumer's magnitude of contractual burden. Also, phrasing referring to "circumstances beyond the trader's control" or similar is often scrutinized carefully, especially Article 471 of the Civil Code prescribes liability in respect of loss that ensued as a consequence of non-performance or undue performance of a contractual obligation, except those instances where non-performance or undue performance is a consequence of circumstances for which the party shall not be liable. This formulation is to be interpreted strictly, and a contractual stipulation to the effect that the trader's liability is excluded in respect of loss arising "for reasons unattributable to him" has been deemed an unwarranted broadening of this scope ${ }^{27}$. In respect of exclusions of liability for losses arising by virtue of disruptions in the provision of electronic banking services, it is an insufficient justification for the bank to claim the necessity of undertaking modificatory or maintenance works or that the consumer had been properly informed beforehand ${ }^{28}$.

Justifiably, it is impermissible for banks to refuse to accept or attempt to limit liability where a credit card holder is unable to access their funds where his card is rejected by a cashpoint or a card terminal. This applies also where such an exclusion or limitation is circumscribed to reasons fall-

25 Judgment of the Court of Competition and Consumer Protection of 10 December 2009, ref. number XVII Amc 1577/09.

26 Judgment of the Court of Competition and Consumer Protection of 20 October 2010, ref. number XVII Amc 1335/09.

27 Judgment of the Appellate Court for Warsaw of 14 November 2014, ref. number VI ACa 116/14; judgment of the Appellate Court for Warsaw of 18 June 2013, ref. number VI ACa 1632/12; judgment of the Court of Competition and Consumer Protection of 27 November 2017, ref. number XVII AmC 1541/15.

28 Judgment of the Appellate Court for Warsaw of 21 December 2011, ref. number VI ACa 873/11. 
ing beyond the control of the bank ${ }^{29}$. For it is often excessively difficult to determine upfront whether a particular instance of card rejection is due to reasons attributable to the bank. In any given instance there are at least two entities potentially at fault - the bank, a cashpoint or card terminal manufacturer or the intended recipient of a payment. It is detrimental to consumers' economic interests for a bank to disclaim liability where the exact source thereof may be hardly possible to ascertain. Crucially, it is the bank that gave itself a unilateral right to determine what constituted "important reasons" for the purposes of exercising perhaps the most important right a contractual party may have, i.e. termination, and it should be added that in the case analysed by a Polish Appellate Court in this matter, no consequences were tied to premature termination.

An important legal avenue guarded by consumer protection courts as regards shielding consumer economic interests consists in prohibiting traders and sellers from relieving themselves of liability for acts and omissions committed by their agents and representatives used thereby to render goods and services for the benefit of the consumer ${ }^{30}$. It has been surmised that clauses analyzed in the previous paragraph (excluding liability for loss caused due to reasons unattributable or otherwise beyond the control of the trader) may have the effect of excluding or excessively limiting the trader's liability by virtue of acts and omissions of third parties engaged thereby to perform for the benefit of the consumer ${ }^{31}$. Again, however, even though this point is explicable by reference to the classic concepts of pecuniary loss and causation, the courts are reluctant to express their reasoning in such terms, relying instead on the fact that such clauses are liable to trigger in

29 Judgment of the Appellate Court for Warsaw of 7 June 2013, ref. number VI ACa $1599 / 12$.

30 Judgment of the Appellate Court for Warsaw of 14 January 2011, ref. number VI ACa 778/10; judgment of the Appellate Court for Warsaw of 17 October 2012, ref. number VI ACa 576/12; judgment of Appellate Court for Gdańsk of 12 December 2012, ref. number I ACa 695/12; judgment of the Court of Competition and Consumer Protection of 22 January 2013, ref. number XVII Amc 368/12; judgment of the Appellate Court for Warsaw of 3 July 2014, ref. number VI ACa 1313/13; judgment of the Appellate Court for Warsaw of 3 April 2017, ref. number I ACa 1465/15.

31 Judgment of the Court of Competition and Consumer Protection of 27 November 2017, ref. number XVII Amc 1541/15. 
consumers a false conviction that the scope of "reasons unattributable to the trader" is the same as "circumstances for which the party shall not be liable" in Article 471 of the Civil Code, whilst in reality it clearly is not ${ }^{32}$. Notwithstanding, there are outliers, and it has been noted that the consumer's economic interest is abridged (grossly violated) by depriving him of remedies in respect of loss stemming delays in the performance of a consumer agreement caused by actions or omissions of engaged third parties ${ }^{33}$.

The trader cannot exclude its liability as against the consumer in respect of physical defects of a product, even where it constitutes a prize in a contest organized by an institution exclusively for its clients ${ }^{34}$. Once the trader holds itself out to provide a service or product, thus encouraging consumers to incur expense (typically eligibility to participate in such contests or lotteries is restricted to paid members), it must follow through as regards its quality and may not exclude the default rules of liability in respect of product guarantees. This applies especially since such an exclusion creates an imbalance of rights in that the trader is always in its right to sue the provider of the prize product. To exclude liability in such a case could amount to unjust enrichment on the part of the trader. It is also impermissible to assign liability to a third party that is not contractually linked with the consumer ${ }^{35}$,

\section{CLAUSES THAT EXCLUDE OR SUBSTANTIALLY LIMIT THE RIGHT TO SET OFF THE CONSUMER'S RECEIVABLE AGAINST THE OTHER PARTY'S RECEIVABLE}

It has been confirmed by the Supreme Court that substantial limitations of set-off rights are permissible only as between professional entities

32 Judgment of the Appellate Court for Warsaw of 27 January 2011, ref. number VI ACa 770/10; judgment of the Regional Court for Łódź of 8 December 2016, ref. number III Ca $1395 / 16$.

33 Judgment of the Court of Competition and Consumer Protection of 27 November 2017, ref. number XVII AmC 1541/15.

34 Judgment of the Appellate Court for Warsaw of 21 December 2011, ref. number VI ACa $873 / 11$.

35 Ibid. 
(or where both counterparties are consumers), and to be stricken down in the context of a consumer agreement a disputed clause must either exclude or substantially limit the right of set-off ${ }^{36}$. The set-off right is generally accorded pursuant to Article $498 \$ 1$ of the Civil Code ${ }^{37}$.

A model of dealing with violations of economic interests by virtue of excluding or significantly limiting set-off rights is provided in the judgment of the Appellate Court for Warsaw of 25 January $2012^{38}$. The clause in dispute there barred the consumer from setting off his receivables as against the bank acquired from third parties with receivables the bank has against that consumer. On its face, the agreement allowed the consumer to set off those receivables against the bank which had its source in the consumer's own assets and were not traceable to any third party. Courts at both instances stressed that the clause unevenly distributes rights and obligations in that no limitation whatsoever was placed on the bank's ability to set off. Having recounted the term's incompliance with Article 498 of the Civil Code, the first instance court further explained that it also breached Article 504 which excludes the redeeming of a receivable by way of set-off only in the event of an acquisition of a receivable by a third party only where the debtor became its creditor's creditor only after the acquisition or where his receivable became payable after that moment. Interestingly, the Appellate Court ventured to assert that actions in breach of consumer interests cannot be justified by the bank's intention to maintain liquidity and an overall sustainable financial standing of the organization. Despite the bank being bound by the Banking Law ${ }^{39}$ (Article 8) to maintain liquidity with a view to meeting all financial obligations towards its clients, attainment of this objective cannot be carried out by means of measures falling foul of consumer protections. As the consumer was barred

36 Judgment of the Supreme Court of 25 July 2013, ref. number II CSK 191/13.

37 "If two persons are simultaneously debtors and creditors with regard to each other, each of them may set off their receivable against the receivable of the other party, if the object of both receivables is money or things of the same quality specified as to their kind and both receivables are mature and may be pursued before a court of law or before another state organ".

38 Ref. number VI ACa 856/11.

39 Act of 29 August 1997 - Banking Law (consolidated text: Official Journal of Laws of 2018, item 2187). 
from setting off receivables acquired in any manner (be it through a sale and purchase agreement, exchange, donation, etc.), this was too substantial of a limitation, one that distorted the balance of competing consumer and bank interests. The significance of the judgment lies primarily in the court's strong and unwavering approach to economic justifications large institutions could put forward for not adhering to standards imposed by consumer legislation. Often burdensome regulatory requirements cannot be adhered to at the consumer's expense.

\section{CLAUSES WHICH INCLUDE THE TERMS WHICH THE CONSUMER MAY NOT HAVE ACQUAINTED HIMSELF WITH PRIOR TO THE CONCLUSION OF THE CONTRACT}

Within the heading's scope caught are clauses which envisage the right of a service provider or seller to change the terms of or cease to provide services in accordance with the relevant consumer agreement ${ }^{40}$ where such clauses to come into effect do not require acceptance of the other party, are detached from important reasons specified in the agreement, and therefore grossly violate consumer interests. Not only do such clauses expose the consumer to the risk of bearing financial loss in the event of an adverse change of terms, but are also liable to induce disappointment where he is deprived of the right to make use of certain services he was previously entitled to. Quantifiable loss meets non-financial loss, as it does in the case where a consumer's use of new functionalities or options by virtue of a service agreement is equated by a contractual term with equating certain provisions of the general terms of use ${ }^{41}$. No prior knowledge of the terms is required for a consumer to assent to pre-drafted terms, which creates a tangible risk of being unknowingly subjected to onerous economic obligations.

It has been hinted that for a document to be admitted as evidence in the proceedings concerning the classification of a contractual term as

40 Judgment of the Court of Competition and Consumer Protection of 9 March 2011, ref. number XVII AmC 3356/10.

41 Judgment of the Appellate Court for Warsaw of 21 December 2011, ref. number VI ACa 873/11. 
unfair before the Court of Competition and Consumer Protection it shall be proven, with a view to establishing that a given text (ancillary to the underlying consumer agreement) was binding on the consumer, that he had a real chance of familiarizing himself therewith before the conclusion of such an agreement ${ }^{42}$.

\section{CLAUSES THAT ALLOW THE ASSIGNMENT TO A THIRD PARTY OF RIGHTS AND OBLIGATIONS UNDER A CONTRACT WITHOUT THE CONSUMER'S CONSENT}

Stability and continuity of a consumer contractual relationship requires that the parties to any given contract coming within the scope of control of unfair terms shall stay intact for the entire duration of the contract. This necessitates limiting the rights of assignment. Assignment of a consumer's rights and/or obligations under a consumer contract may have profound ramifications for his economic standing. It is often impracticable or excessively onerous for a consumer to predict the future new creditor's aggressiveness in pursuing its receivables, adherence to the black letter of the contract, or potential further disposals to other third parties, often aimed at generating profit through sales of receivables.

Polish case law on this point illustrates the need for accurate drafting, revealing a void in the Polish regime of unfair terms. The Supreme Court has applied a literal construction to Article $385^{3}$ point 5 of the Civil $\mathrm{Code}^{43}$ that prima facie the trader may assign its receivables under a consumer contract without the consumer's consent ${ }^{44}$. In doing so, it overturned the judgment of the Appellate Court for Katowice ${ }^{45}$ which held

42 Judgment of the Court of Competition and Consumer Protection of 24 August 2012, ref. number XVII AmC 2600/11.

43 The provision states that prohibited are terms which "allow the other contracting party to transfer the rights and convey duties arising from the contract without the consumer's consent".

${ }^{44}$ Judgment of the Supreme Court of 26 September 2008, ref. number V CSK $105 / 08$.

45 Judgment of the Appellate Court for Katowice of 28 September 2007, ref. number V Aca 516/07. 
that a transfer of a receivable having arisen under a consumer contract requires consent of the consumer. This was inferred by reference to Article 509 of the Civil Code under which such a transfer carries with it all rights attached therewith, unless such an effect is contrary to statute, a contractual stipulation or the nature of the underlying obligation. As the contract in dispute did not contain an individually negotiated term expressing the consumer's consent to an assignment (or that consent was necessary for such an assignment to be effective), rights and duties cannot be assigned where the underlying contract is silent thereto.

The Supreme Court restricted the prohibition in Article $509 \$ 1$ of the Civil Code exclusively to transfers of receivables (i.e. transfers of "rights"), as opposed to transfers of "rights and duties" envisaged by Article $385^{3}$ point $5^{46}$. It was held that since Polish law does not envisage transfers of "rights and duties" by means of a single transaction ${ }^{47}$, to effect a transfer of "rights and duties" contemplated by Article $385^{3}$ point 5 , two distinct transactions typified in the Civil Code are necessary - a transfer of rights followed by a transfer of debts under one contract. Therefore, as consumer legislation prima facie prohibits merely transfers of rights and

46 To be more precise, the prohibition applies only to transfers where rights and duties of the trader under a consumer contract are assigned together by means of a single transaction. For more on this, see: judgment of the Supreme Administrative Court of 6 June 2005, ref. number I OPS 2/05; Tomasz Czech, Kredyt Konsumencki. Komentarz, Warszawa: Wolters Kluwer, 2018, 486.

47 Technically speaking, two transactions are necessary: first, a transfer of receivables under Article 509, followed by a transfer of obligations (or debts) by virtue of Article 519 of the Civil Code. Cf. Artur Krzykowski, "Umowne ograniczenia przelewu wierzytelności w kodeksie cywilnym - propozycja reinterpretacji i wnioski de lege ferenda”, Przegląd Prawa Handlowego 5 (2011): 39-47 (who argues in favour of a hybrid construction to bring consumer proetction laws in line with private law orthodoxy); Marek Jasiakiewicz, "Wokół dopuszczalności cesji niektórych wierzytelności konsumenckich", Przegląd Prawa Handlowego 8 (2005): 19-25 (written before the Supreme Court's decision, it envisaged certain circumstances under which prior consumer consent was absolutely necessary for an assignment to go through); Paweł. Mądry, "Dopuszczalność przelewu wierzytelności konsumenckiej”, Glosa 11 (2004): 19-22 (it argued that transfers of receivables are permitted, and soi $\mathrm{t}$ is consistent with the tenor of the subsequent Supreme Court's judgment); Magdalena Szczepańska, "Prawo do dokonania przelewu wierzytelności z umowy ubezpieczenia”, Temidium 1 (2010), pp. 59-63; Witold Jarzyński, “Zmiany podmiotowe w umowach”, Monitor Zamówień Publicznych 6 (2011): 59-61. 
duties effected as one compact transaction, it cannot prohibit a partial transaction consisting exclusively in a transfer of rights. The Court noted that only in respect of certain specific contractual relationships the Civil Code envisages a compact transfer (assignment) of all rights and obligations (lease agreements and contract farming - see Articles $678 \$ 1$ and $691 \$ 1$, as well as 625 and $626 \$ 1$, respectively), but these exceptions shall not be extended without explicit statutory authorization. Importantly, the Supreme Court also disapproved of the Appellate Court's assertion that Article $385^{3}$ prohibits a transfer of a receivable where the contract at hand is silent as to such a possibility - the provision was said to pertain to unfair terms and its reach ends where a given contract is devoid of such terms. This potentially limits the judicial ambit of control, implicitly greenlighting an attitude where the trader intentionally omits a potentially vulnerable right of its own or an obligation of the consumer (one that is reasonably demandable) for fear of it falling under the scope of protection from unfair terms, nevertheless relying on it under convenient circumstances - in which case, it appears, he would be shielded from the consumer's protest.

The above means that, at least in Polish law, the consumer is afforded limited protection in relation to change of creditor, which amounts, effectively, to partial protection in the event of assignment. It is relatively well established that the trader or seller may transfer the receivable and rights related thereto to a third party ${ }^{48}$, however it is unknown whether the same logic applies to a mere transfer of obligations. The Supreme Court has opined that the objective of Article 3853 point 5 was, in the eyes of Parliament, to shield the consumer from an anticipated change of

48 The Supreme Court judgment of 26 September 2008 has been affirmed in such judgments as: judgment of the Supreme Court of 11 December 2009, ref. number V CSK 184/09; judgment of the Supreme Court of 7 April 2011, ref. number IV CSK 422/10; judgment of the Appellate Court for Warsaw of 17 October 2012, ref. number VI ACa 576/12; judgment of the Regional Court for Lublin of 11 June 2013, ref. number II Ca 386/13. Interestingly, the judgment has been cited in support of the thesis that Article $385^{3}$ of the Civil Code is a transposition of the Annex to Directive 93/13 and is aimed at strengthening consume protection in the realm of unfair terms - although it appears that on the facts it actually contributed to the diminution of that protection. See the judgment of the Supreme Court of 2 April 2015, ref. number I CSK 257/14. 
counterparty obliged to perform in accordance with the terms of the contract ${ }^{49}$. If this is true, then prima facie a transfer of debts should require consent as it leads to a change of the counterparty obliged to perform. The effect of the Supreme Court's pronouncement is that a change of the party obliged to accept the consumer's performance does not require consumer consent whilst a change of the counterparty obliged to perform does. This leaves the state of the law wanting and with much to be desired in terms of consistency. It is submitted that Article 509 should be interpreted widely enough to encompass individual transfers of rights or duties - perhaps the problem resides in the formulation of Article $385^{3}$ point 5 which refers to "rights and duties" - a replacement of "and" with "or" is recommended.

\section{CLAUSES THAT MAKE THE CONCLUSION, THE CONTENT OR THE PERFORMANCE OF THE CONTRACT DEPENDENT ON THE CONCLUSION OF ANOTHER CONTRACT WHICH IS NOT DIRECTLY RELATED TO THE CONTRACT COMPRISING THE PROVISION WHICH IS SUBJECT TO THE ASSESSMENT}

Consumer contracts shall be considered self-contained, independent of any other contractual relationships whose conclusion almost invariably has economic ramifications for the promisee and promisor alike. To compel a consumer to seek to enter into another arrangement inherently imposes on such a consumer an additional cost, and effectively deprives them of a benefit they would have obtained had such an obstacle not been in place.

A practical example in point from the case law is a clause which mandates, in the context of a high LTV insurance agreement ${ }^{50}$, that where

${ }^{49}$ Judgment of the Supreme Court of 26 September 2008, ref. number V CSK $105 / 08$.

50 An agreement by virtue of which the lending bank seeks to ensure the risk it bears by virtue of the relatively low amount of down payment as against the value of the loan granted to a consumer. For more, see: Brent W. Ambrose, Anthony B. Sanders, "High LTV Loans and Credit Risk". September 20, 2002 https://ssrn.com/abstract=355180 [date of access: 01.01.2019]. 
the debt covered by such an agreement has not been paid off in its entirety after 36 months since the agreement's conclusion, the agreement is to continue, albeit no longer than 108 months after the signing of the underlying mortgage loan contract, provided that the lendee entitles the bank to charge as repayment of costs $3.50 \%$ of the difference between the required down payment and the down payment actually made plus repayment of costs that arose by virtue of the continuation of the insurance agreement ${ }^{51}$. Securitization of the loaned amount by virtue of a high LTV insurance agreement is but one available methods of mitigating the risks related to repaying a loan granted despite a low down payment. Importantly, such insurance agreements are concluded between banks and insurers, to the exclusion of consumers. Therefore, even though the latter bear the costs of such agreements, and the risk of dealing with recourse claims by insurers where a payment under the policy is made to the bank, they obtain no benefit from the conclusion nor the subsistence of the insurance agreement. For the consumer to bear the costs of the high LTV insurance agreement effectively constitutes a condition for his eligibility for a mortgage loan. The Court of Competition and Consumer Protection has opined that such an arrangement would be permissible only where the consumer were a party to such an insurance agreement or were a third party benefited by its existence ${ }^{52}$. The availability of alternative type of security is also relevant - it is unnecessary (and indeed unwarranted and impermissible) for a bank to enter into a high LTV insurance agreement at the expense of the consumer where it is by default entitled to benefit from a mortgage charge on a home. To provide for a dual security in such a case has been ruled gratuitous ${ }^{53}$.

51 As reported in the judgment of the Court of Competition and Consumer Protection of 24 August 2012, ref. number XVII AmC 2600/11.

52 Judgment of the Appellate Court for Warsaw of 20 November 2013, ref. number VI ACa 1521/12; confirmed numerous times in the judgments of regional courts, including as of late: judgment of the Regional Court for Warsaw of 5 October 2017, ref. number XXVII Ca 2910/16; judgment of the Regional Court for Łódź of 27 November 2017, ref. number III Ca 1082/17.

53 Judgment of the Appellate Court for Warsaw of 23 October 2012, ref. number VI ACa 550/12; judgment of the Court of Competition and Consumer Protection of $24 \mathrm{Au}-$ gust 2012, ref. number XVII AmC 2600/11. 


\section{CLAUSES THAT MAKE THE PERFORMANCE DEPENDENT ON THE CIRCUMSTANCES WHICH DEPEND ON THE OTHER CONTRACTING PARTY'S INTENT ALONE}

Another category consists of clauses which make automatic renewal of a consumer agreement independent of the will of the consumer, potentially subjecting him to unwanted financial loss ${ }^{54}$. The clause must stipulate the time period by which the agreement is to be extended, even where an extension is predicated upon circumstances beyond the trader's or the consumer's control, including force majeure ${ }^{55}$. The trader cannot be given an unfettered right (and full discretion associated therewith) to assess the impact of a consumer's contractually permissible action on the bindingness of another contract, even a closely related one ${ }^{56}$.

Traders may, however, subject their performance to the condition that the consumer refrain from tortious liability by virtue of fault or gross negligence. It is a sufficient safeguard for the consumer's interests and in compliance with the requirement of good faith that resource may be had to court intervention. No additional steps must prima facie be taken by a trader - a consumer's wrongful act absolves, as it were, the trader from the safeguarding duty ${ }^{57}$.

\section{CLAUSES THAT GRANT TO THE OTHER CONTRACTING PARTY A RIGHT TO CARRY OUT A BINDING INTERPRETATION} OF THE CONTRACT

The right to unilaterally interpret provisions of a consumer contract is potentially very dangerous to consumer economic interests. An interesting

54 Judgment of the Appellate Court for Warsaw of 20 November 2013, ref. number VI ACa $1521 / 12$.

55 Judgment of the Court of Competition and Consumer Protection of 24 October 2017, ref. number XVII AmA 69/15.

56 Judgment of the Appellate Court for Warsaw of 19 June 2013, ref. number VI ACa $1545 / 12$. The case concerned a unit-linked life insurance policy (a genus of insurance with investment elements).

57 Judgment of the Appellate Court for Łódź of 22 October 2013, ref. number I ACa $494 / 13$. 
example is a clause that excludes the trader's liability in respect of losses caused by decisions of public authorities. Not only does such a clause unwarrantedly limit the trader's liability in respect of undue performance of the agreement, but it also avails itself of an ambiguous term of "public authority", effectively licensing the trader to offer its own autonomous interpretation which, as one may surmise, would opportunistically suit his interests depending on the facts of a particular case ${ }^{58}$. Another case, one which explores the problem of unilateral interpretation in depth, concerned a clause which conditioned the provision of transport from an accident site upon the lack of necessity of emergency rescue services intervention and difficulty in using an available public or private means of transport ${ }^{59}$. Terms "difficulty" and "necessity of emergency rescue services intervention" were considered ambiguous (and therefore not expressed in "plain and intelligible language", contrary to Article 4(2) of Directive 93/13) in the light of available medical knowledge and expertise as well as various physical and mental states the insured may be in. Even though it is a medical professional who makes a relevant decision on sending out an ambulance, assessment of a victim's condition is made "at arm's length", arbitrarily, and on behalf of the consumer's counterparty (a life insurance provider). The contract in dispute failed to particularize whether the term "availability of a public or private means of transport" depends exclusively on the health condition of the insured or whether it also encompasses such factors as distance to the destination or the financial condition of the insured. The insurer also reserved the right to deny coverage by availing itself of wording such as "the insurer may return the cost...", thus defying the essence of an insurance contract which lays down, inter alia, certain absolute obligations of the insurer should specific occurrences eventuate.

The courts have not been clear on the level of participation (or say) to be accorded to consumers for a clause not to be found unfair. It may be the case that it is sufficient to lay out the criteria a trader will be guided by

58 Judgment of the Appellate Court for Warsaw of 21 December 2011, ref. number VI ACa 873/11; judgment of the Appellate Court for Warsaw of 2 February 2017, ref. number VI ACa 1811/15.

59 Judgment of the Appellate Court for Warsaw of 9 February 2012, ref. number VI ACa 1472/11. 
in making decisions under a clause, even where no consumer intervention is permitted ${ }^{60}$. This leads to a conundrum: a trader may purposely use ambiguous and general language to vaguely delineate the boundaries of its discretion as regards contractual interpretation and still have a shield against potential consumer claims. Polish courts have, on occasion, been relatively strict in their interpretation in terms of the level of latitude accorded to traders. In one case, a clause which specified the maximum period for considering a product complaint as "approximately 21 days plus time requisite for delivery and/or postage" was construed as giving the trader the right to impose its own interpretation of a salient contract term on the consumer, despite the fact that delivery time ${ }^{61}$, despite the fact that traders should not ordinarily be held accountable for delivery time. The argument goes that such a formulation misinforms consumers, thus creating a misguided expectation as to the deadline for consideration of complaints. Also, it upsets a legitimate expectation of the consumer, one that consists in knowing a timeframe within which a complaint is to be considered.

That traders should not burden consumers with a binding construction of a contract, often in a way that leaves consumers in the dark as to the exact meaning of key stipulations and defies their reasonable expectations, has been used to distil a wide-reaching principle of fair and reasonable formulation of the principles governing a trader's liability ${ }^{62}$. Therefore, it is impermissible and dangerous to a consumer's economic interests to predicate a bank's right to terminate a credit card agreement upon "important reasons" such as a "gross violation by the cardholder of any provision of the agreement or Terms of Use" or the materialization of circumstances which, in the opinion of the bank, may have an "adverse effect" on the ability of the cardholder to meet their financial obligations towards the bank, "regardless of their legal basis", or that there arises a "reasonable suspicion" that the cardholder committed a financial crime. Generally, it appears consumer contracts should use general clauses sparingly and cautiously.

60 Judgment of the Court of Competition and Consumer Protection of 24 August 2012, ref. number XVII AmC 2600/11.

${ }^{61}$ Judgment of the Appellate Court for Warsaw of 6 November 2013, ref. number VI ACa $1077 / 13$.

62 Judgment of the Appellate Court for Warsaw of 7 June 2013, ref. number VI ACa $1599 / 12$. 


\section{CLAUSES THAT ENTITLE THE OTHER CONTRACTING PARTY TO CHANGE THE CONTRACT UNILATERALLY WITHOUT AN IMPORTANT REASON SPECIFIED IN THE CONTRACT}

Under Polish law, any unilateral change to a consumer contract must be exacted for important reasons specified a priori in the agreement. In addition, the courts have found a duty of the trader to give the consumer a chance to acquaint himself with the trader's intention to introduce such changes beforehand, and consent of the consumer is essential for any changes to go through ${ }^{63}$. It appears, however, that phrasing which implies the permissibility of changes other than those envisaged in the agreement (such as "the agreement may be amended due to important reasons, in particular...") is not likely to be found unfair ${ }^{64}$.

Economic interests of the consumer may also be grossly violated in relation to contests or competitions organized for the benefit of clients of a given establishment, say a bank. Such contests may not be, once set up, stipulated to be terminable at any time and for any reason, and it is an insufficient safeguard of consumer interests that information about such a fact is to be published online ${ }^{65}$. The organizer is also not entitled to change the prize as it pleases - the consumer has a legitimate expectation that it remains the same throughout the duration of the contest ${ }^{66}$. For it is conceivable that a consumer previously agreed to open an account with the bank in question, took out a credit card (for which he regularly incurs charges) for the purpose of participating in the competition, therefore its direct termination may trigger in the consumer feelings of disappointment, lost chance, discomfort. Such a consumer is ready to go

${ }^{63}$ Resolution of the Supreme Court of 22 September 2016, ref. number I CSK 814/15; judgment of the Supreme Court of 14 May 2015, ref. number II CSK 768/14; judgment of the Supreme Court of 19 March 2007; ref. number III SK 21/06.

${ }^{64}$ Judgment of the Court of Competition and Consumer Protection of 9 March 2011, ref. number XVII AmC 3356/10.

65 Judgment of the Appellate Court for Warsaw of 21 December 2011, ref. number VI ACa 873/11.

${ }^{66}$ Judgment of the Appellate Court for Warsaw of 15 February 2012, ref. number VI ACa 1101/11; judgment of the Appellate Court for Warsaw of 4 October 2011, ref. number VI ACa 282/11. 
to great lengths to win - he may share his personal data with the bank or continue to unknowingly perform non-cash transactions long after the contest is terminated with winning the contest being the sole objective in his mind.

We can see how the concept of violation of consumer interests transcends the traditional meaning of "loss", even taking account of lucrum cessans (lost benefits). What is also apparent is that whilst lost chance might not form sufficient grounds for recovery under the traditional principles of civil law ${ }^{67}$, it is often quantifiable as an economic encumbrance. Disappointment is typically non-recoverable unless a serious mental impairment is caused thereby. What is recoverable, however, is financial loss engendered by virtue of these disadvantages. It is not indispensable to warp the notion of "loss" in order to properly serve and safeguard consumer interests. What effectively is being claimed, I submit, is the financial equivalent for the time lost (or, to put it more accurately, the money-making opportunities taken away) on not being able to pursue a quantifiable objective capable of being expressed in monetary units. This view may appear reductive and take lightly the mental and intellectual side of human sensibilities and actual real-life experiences, however one must remember that the courts remedy this type of discomfort by means of pecuniary compensation. The courts must be able to quantify the extent of violation a consumer's interests suffered (which need not be equal to "loss" in its traditional sense, understood as damnum emergens and lucrum cessans), and this is done typically by reference to the financial value of opportunities a consumer was forced to forfeit as a result of a trader's conduct. In other words, the consumer claims (often inadvertently as the ultimate amount of damages is determined by a judge) for an amount he could have reasonably produced himself had it not been for an infraction of his interests in the gravity and frequency perpetrated by the trader. Account may be taken of the latter's superior bargaining position to adjust this amount.

${ }^{67}$ Pertinently, participants in lotteries have been held to be barred from claiming for the prize amount where they had been deprived of an opportunity to win. See: Piotr Sitnik, "Searching for a Rationale for Compensating Loss of a Chance in Polish Tort Law. Lessons to be Learned from England and Wales", Review of Comparative Law 3 (2017): 9-19. 


\section{FINAL REMARKS}

The cases analysed above included scenarios where, inter alia, consumers were limited in their right to inspect a product they ordered; excessive penalties for (even accidental) violations of the trader's terms of use; the trader had virtually unlimited discretion in interpreting the contract's provisions; ineffective clauses were imposed which absolved the trader of liability for adverse consequences resulting from gaining by a third party access to the balance of a consumer's internet account; the consumer was barred from setting off his receivables as against the bank acquired from third parties with receivables the bank has against that consumer. What links these situations up is the fact that the clauses proffered by traders there did not directly encroach upon the consumer's economic wellbeing. They did not "take anything away" from the consumer in terms of immediate monetary, material or financial value. What they did, however, was to tilt the balance of rights and obligations towards the trader by, broadly speaking, according it the right to expand its prerogatives beyond what was already written in the contract as signed by the parties. What the analysis offered in the paper shows is that whilst the courts will normally shy away from questioning a contract's initial letter, including its financial terms governing price and remuneration, intervention may be warranted where an unfair mechanism is utilized to either minimize the consumer's recourse to compensation or indemnity or, on the other hand, to maximize the trader's opportunities to exploit the consumer's economic fragility.

\section{REFERENCES}

Ambrose, Brent W. and Sanders, Anthony B. 2002. "High LTV Loans and Credit Risk”. September 20, 2002), https://ssrn.com/abstract=355180.

Czech, Tomasz. 2018. Kredyt Konsumencki. Komentarz. Warszawa: Wolters Kluwer.

Domurath, Irina, 2017. Consumer Vulnerability and Welfare in Mortgage Contracts. Oxford: Hart Publishing

Jarzyński, Witold. 2011. „Zmiany podmiotowe w umowach”. Monitor Zamówień Publicznych 6. 
Jasiakiewicz, Marek. 2005. „Wokół dopuszczalności cesji niektórych wierzytelności konsumenckich”. Przegląd Prawa Handlowego 8.

Krzykowski, Artur. 2011. „Umowne ograniczenia przelewu wierzytelności w kodeksie cywilnym - propozycja reinterpretacji i wnioski de lege ferenda”. Przegląd Prawa Handlowego 5.

Mądry, Paweł. 2004. „Dopuszczalność przelewu wierzytelności konsumenckiej”. Glosa 11.

Nebbia, Paolisa. 2007. Unfair Contract Terms in European Law: A Study in Comparative and EC Law. Oxford-Portland: Hart Publishing

Szczepańska, Magdalena. 2010. „Prawo do dokonania przelewu wierzytelności z umowy ubezpieczenia”. Temidium 1.

Schillig, Michael. 2011."Directive 93/13 and the Price Term Exemption: A Comparative Analysis in the Light of the Market for Lemons Rationale". International and Comparative Law Quarterly 60(4)

Sitnik, Piotr. 2017. "Searching for a Rationale for Compensating Loss of a Chance in Polish Tort Law. Lessons to be Learned from England and Wales". Review of Comparative Law 3. 
